\title{
BMF Gene
}

National Cancer Institute

\section{Source}

National Cancer Institute. BMF Gene. NCI Thesaurus. Code C104158.

This gene plays a role in apoptosis. 